\title{
An Overview of Biochar Production and Biochar Producing Stoves in Bangladesh
}

\author{
Md. Sadekur Rahman ${ }^{1}$, Md. Enamul Haque ${ }^{2}$, Md. Rubayet Al Ferdous Noman ${ }^{3}$ \\ ${ }^{1}$ PhD Fellow, ${ }^{2}$ Professor, Department of Agricultural Extension and Rural Development, Bangabandhu Sheikh \\ Mujibur Rahman Agricultural University, Gazipur, ${ }^{1}$ Associate Professor, ${ }^{3}$ Lecturer, Department of Agricultural \\ Extension, Hajee Mohammad Danesh Science and Technology University, Dinajpur, Bangladesh
}

\begin{abstract}
Biochar is not a newly invented technology; rather its relevance and efficacy have recently come to the front burner. Naturally, it is deposited in the soil through forest and grassland fires. Interestingly, biochar is also produced from biomass by zero or low oxygen environment. However, biochar has gained an international research interest and offers ample scope for further investigations on biochar and biochar producing cooking stove. The present review paper mainly focuses on the status of biochar production and biochar producing stoves with specific emphasis on the status of biochar production technology and the perception, knowledge, and attitude towards biochar production and utilization; use and performance of biochar producing cooking stoves; and problems encountered in biochar production and utilization. Having observed positive perception, and attitude as well as an appreciable knowledge of rural farmers in biochar production and utilization the paper emphasizes the incorporation of a policy framework, training and enhanced access to information for higher agriculture use of biochar and sustainable environment.
\end{abstract}

Keywords - Biochar Production, TLUD, Performance, Utilization, Rural Bangladesh.

\section{INTRODUCTION}

Biochar is fairly an innovative term but not a new element. All over the world, biochar deposited in soil naturally through grassland and forest fires (Krull et al., 2008, Skjemstad et al., 2002). However, biochar is also created by charring of various organic matters, such as firewood or farm wastes under limited or no oxygen environment (Magnusson, 2015). Nowadays, biochar is produced through the process of pyrolysis where the biomass is heated to temperatures typically between $300^{\circ} \mathrm{C}$ and $700^{\circ} \mathrm{C}$ under anaerobic conditions. Although, the term biochar has come into a new common practice while the use of charcoal for improving soil health as fertility management goes back millennia (Scholz et.al, 2014). Hence, biochar is usually made in an eco-friendly way by recycling plant waste into fertilizer (Cui, 2015, McLaughlin et al., 2009; Lehmann, 2009).

There are numerous types of biochar, categorized based on the raw materials (agricultural wastes, forest residues, organic wastes materials) from which it is made. The historical use of biochar as far back as 2000 years ago (O'Neill et al. 2009). In the Amazon basin, evidence of substantial use of biochar can be found in the uncommonly fertile soils renowned as Terra Preta and Terra Mulata, which are the classical document of today's biochar (O'Neill et al. 2009). The existence of these 'dark piles of the earth' is often used to sustenance modern research on biochar (Leach et al., 2010). Moreover, the invention of biochar producing stoves, which provides better cooking and the end product biochar used for soil improvement and reduced the Green House Gas (GHG) (Barrow, 2012).

In 2013, Bangladesh Biochar Initiative (BBI) was formulated to entrench the use of biochar producing stove as an environment-friendly cooking appliance. The Christian Commission for Development in Bangladesh (CCDB) took the responsibility for the invention of low-cost Natural Draft-Top-Lit-Up-Draft (ND-TLUD) gasifiers stove (local name Akha) which can be used for cooking with locally available feedstock. The basic operating principle of an ND-TLUD is very simple and compatible with the women's cooking habits of Bangladesh. (BBI, 2015).

Biochar is an emerging multi-purpose innovation that is rapidly attracting the attention of researchers. The ideal use of biochar is a part of organic waste management. It is proof from biological research that when biochar is mixed with compost it will absorb soluble minerals, and reduce greenhouse gases getting into the atmosphere. The whole biochar systems are typically carbon-negative as well as carbon dioxide sequestering from the atmosphere. It also increases the water-holding capacity, pore size, and distribution of beneficial 
microbes in the soil (FAO, 2010). Transforming biomass into biochar may prevent the emissions of large amounts of carbon dioxide and other greenhouse gases to the atmosphere (Scholz et al., 2014). The technology of biochar has multiple potentials in overcoming many challenges such as efficient biomass management, fostering renewable energy, crop productivity, and mitigating climate change. However, there is a dispute that it is often challenging to produce a huge amount of biochar at a reasonable price for using large scale farms (Duer, 2004). Therefore, the introduction of small-scale biochar producing stoves, allowing local farmers to produce their organic soil amendments while instantaneously generating heat for cooking food. Furthermore, the opportunity to produce their organic soil amendments to the introduction of biochar producing stoves has the potential to greatly reduce levels of hazardous smoke while cooking (Magnusson, 2015). On the other hand, innovative or improved agricultural practices and technologies, such as biochar and biochar producing stoves, may play a significant role in rural and agricultural development (Magnusson, 2015)

By and large, the emphasis on the local production of biochar in Bangladesh is made possible through the introduction of improved stoves (TLUD)/Akha. Furthermore, it is important to note that there are many actors currently working with the development of large scale biochar production systems. But, the status of local small scale production and utilization of biochar in Bangladesh not yet to be compiled. Therefore, given the observed state of affairs in biochar production and utilization in Bangladesh the present paper aims to address the following objectives:

\section{A. Objectives of the Study}

i) overview the status of biochar production technology and the perception, knowledge, and attitude towards biochar production and utilization

ii) evaluate the use and performance of biochar producing cooking stoves; and

iii) review the problems faced in biochar production and utilization.

\section{MATERIALS AND METHODS}

The scientific approach requires a close understanding of the subject matter. This paper mainly depends on secondary information. Different published reports mainly provided input used for this paper. Thus, this paper is completely a review. Therefore no specific method has been followed in preparing this paper. It has been prepared by internet search, comprehensive studies of various articles published in the different thesis, journals, books and proceedings available in the libraries of BSMRAU, HSTU, and Christian Commission for Development in Bangladesh.

Some relevant books and articles have been sourced through extensive searches in for example the Google Scholar and advice from my academic supervisor at BSMRAU, Professor Dr. Md. Enamul Haque. Valuable information has also been collected through personal contact with respective resource personnel to enrich the paper. After the collection of all the related information, it was compiled and logically presented in the present form.

\section{REVIEW OF MAJOR FINDINGS AND DISCUSSION}

Since this paper is entirely a review, the major findings observed are presented here along with suitable discussions in order of the initially stated objectives.

\section{A. Status of Biochar Production Technology}

In modern agriculture, the use of biochar is still evolving. The dedication of institutional capacity to research and development of biochar applications is only now beginning to emerge. An overview of the status of biochar projects globally, particularly in developing countries is shown in Figure 1. The overview came from a survey conducted using the existing electronic network of the International Biochar Initiative (IBI). Findings revealed that the highest number of biochar projects currently works in India and the lowest number of working projects was reported in Bangladesh. 


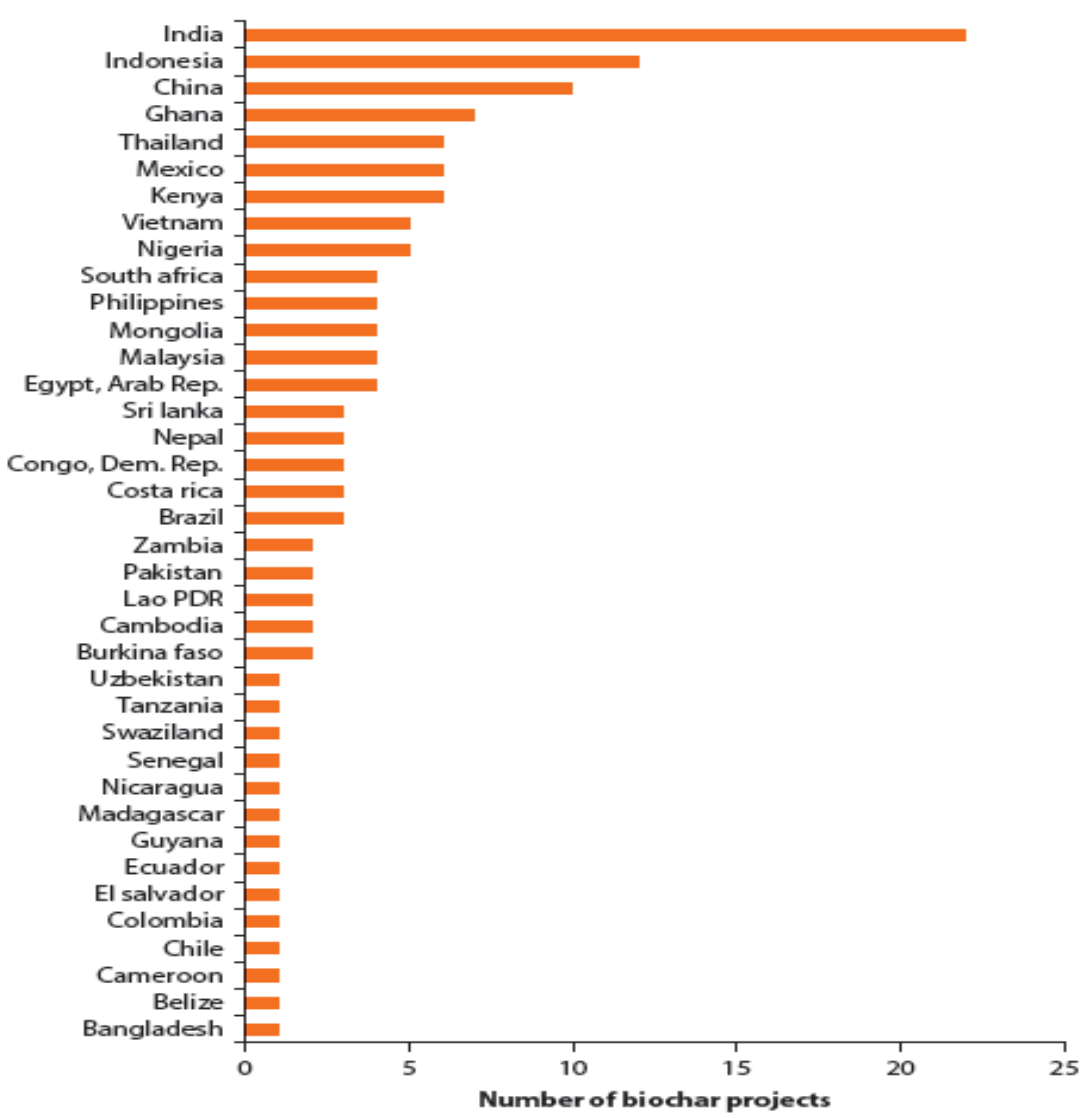

Fig. 1 Biochar project in developing countries (Adapted from: Scholz et al., 2014)

There are many types of biochar production technologies and the choice of technology depends upon the capital investment as well as the purpose(s)or which the biochar is going to be used (Scholz et al., 2014).

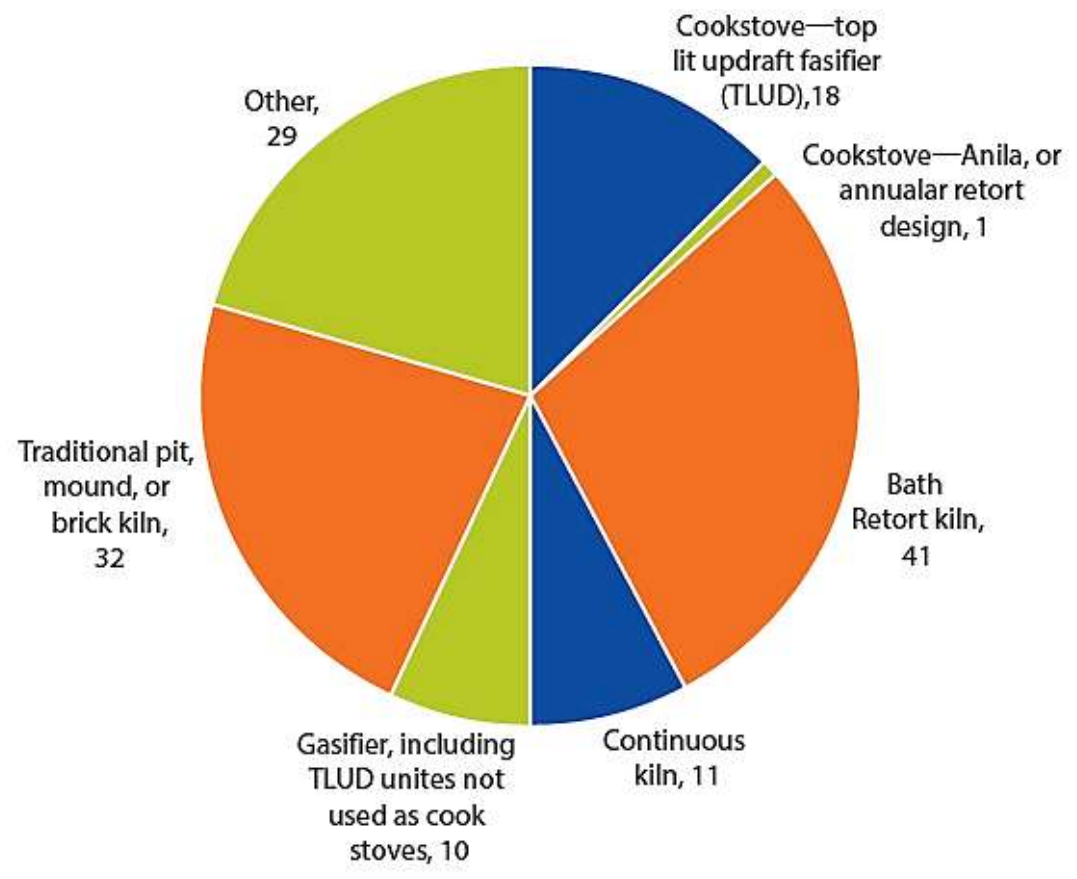

Fig. 2 Biochar production technologies (Adapted from: Scholz et al., 2014) 
Figure 2 showed the different production technologies that survey respondents reported. The choice of technology is closely tied to the available feed stocks. Most of the feed stocks perform best in particular technologies while most suited to handle their characteristics. Findings revealed that Thirty-two (32) percent of the biochar survey respondents make biochar in traditional charcoal pits or mounds while batch retort kilns (41 percent) and continuous kilns (11 percent). The top-lit updraft (TLUD) gasifiers is the most common stove opined by the respondent (18 percent of total), while the anila-style stove (1 percent) used as an annular retort design. Last but not least, comparatively dominant technology (10 percent) is the gasifiers (not used as a cook stove).

Woolf et al. (2010) presented a sustainable biochar concept as shown in Figure3. The Figure 3 indicates that atmospheric $\mathrm{CO}_{2}$ is utilized by green plants during photosynthesis. Pyrolyzation of the biomass results in bio-oil and biochar. Carbonization is a slow pyrolysis process that has been in use for thousands of years, and its main goal is the production of biochar (Panwar et al., 2019).

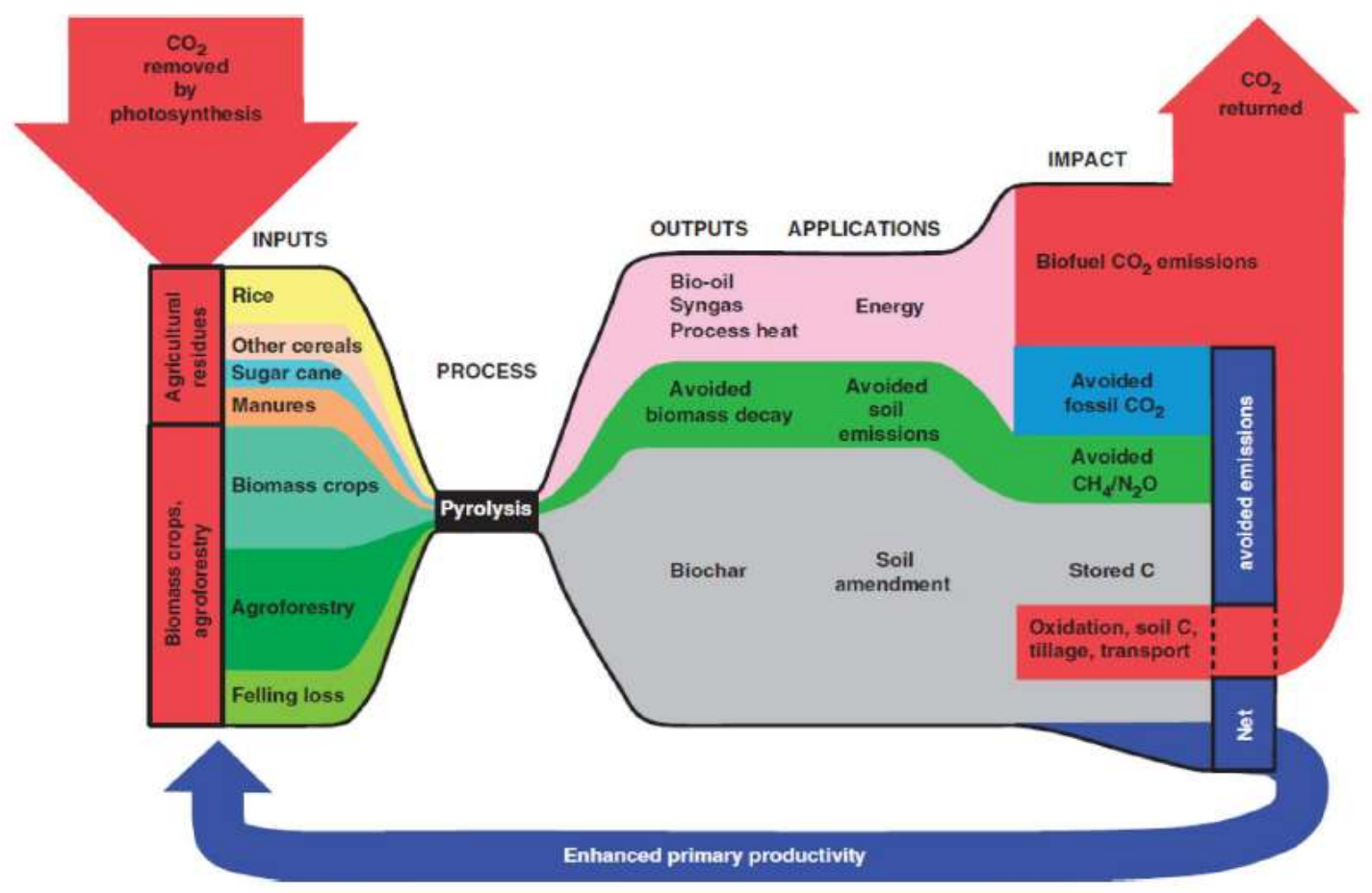

Fig. 3 Various paths for sustainable biochar production (Adapted from: Woolf et al., 2010)

The choice of feedstock biomass for biochar production depends on local availability of material and cost of acquisition including carrying costs. Here, the figure highlighted the different feedstock used (Figure 3 ) for biochar production in different countries. 


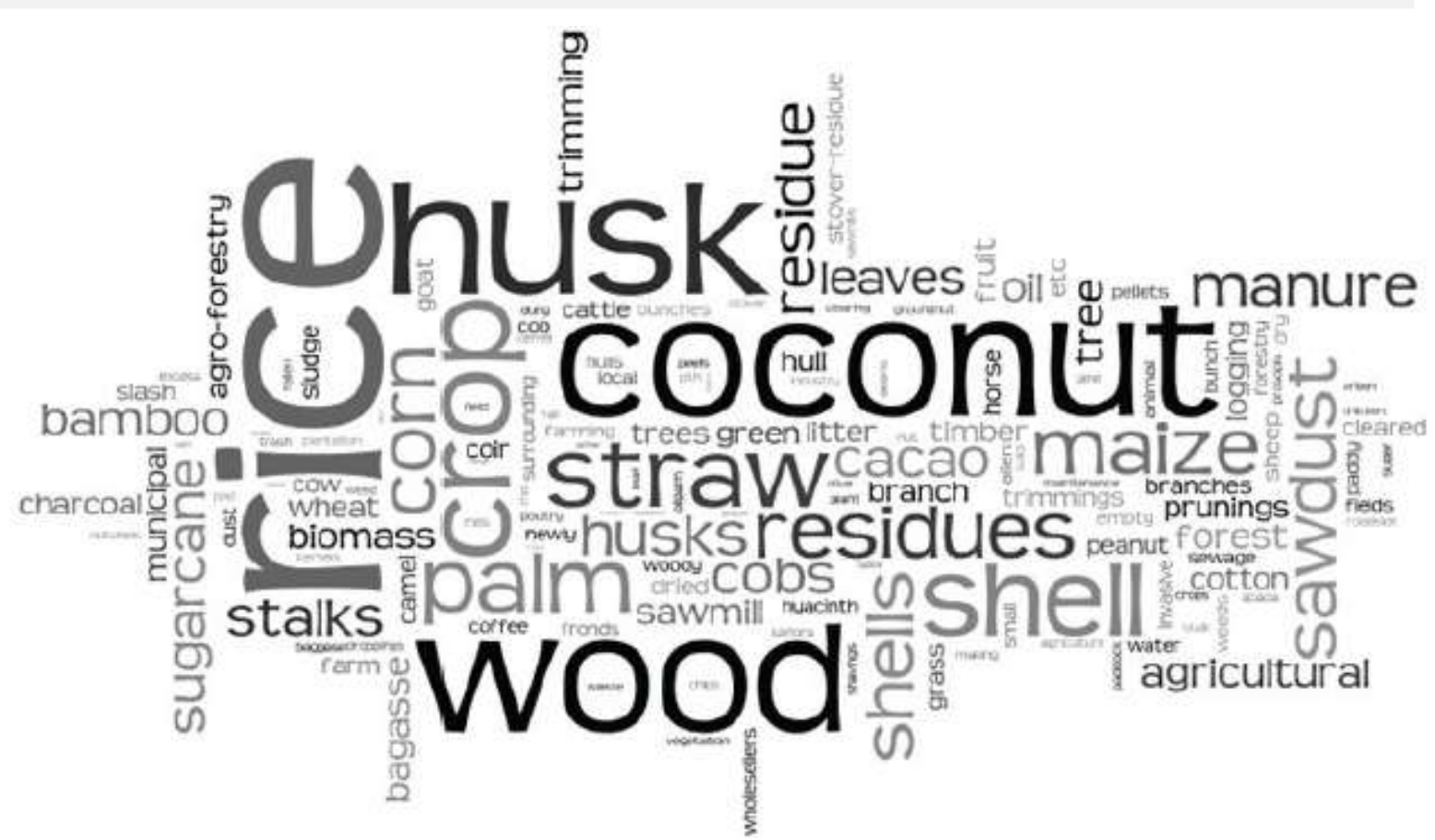

Fig. 4 Word cloud showing biochar feedstock choice (Adapted from: Scholz et al., 2014)

Duku et al. (2011) conducted an experiment on the production of biochar by using an earthen mound kiln in Ghana and they used wood as a feedstock, similarly, Bailis (2009) used wood as a feedstock for charcoal production and reported that the yield of charcoal ranges from 10 to 30 percent when using wood as a feedstock. Joseph et al. (2012) experimented on the North Vietnam villages on the use of biochar and found that greater quantities of biochar produce from the feedstock of rice straw and stock of bamboo, rice husks, tea clippings, and wood. Mwampamba et al. (2013) reported that wood used as a feedstock for charcoal production, using a brick and metal kiln, and found that the efficiency of production fell between 25 and 35 percent.

Gwenzi et al. (2015) reported that in Zimbabwe and other countries in Sub Saharan Africa used crop residues, manure, wood wastes from forestry, wastes from agro-processing industries, aquatic weeds and municipal solid wastes and sewage sludge as a feedstock (Figure 4)

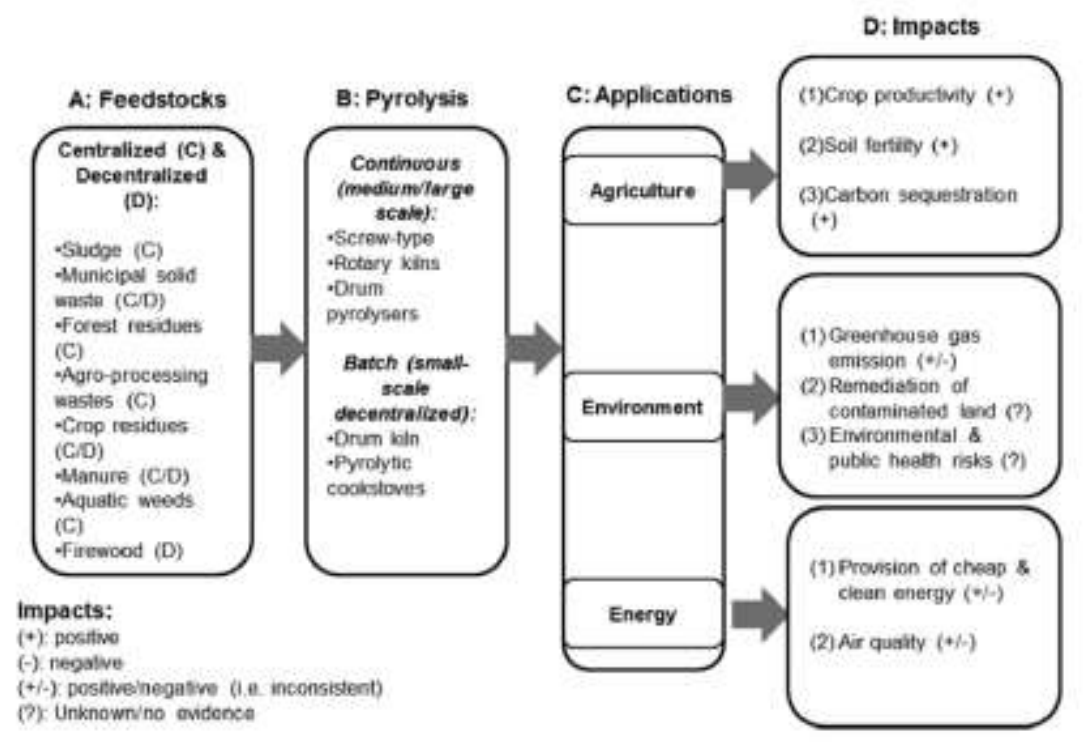

Fig. 5 Biochar production technology in sub-Saharan Africa (Adapted from: Gwenzi et al., 2015) 
In Bangladesh, there is no ready supply of biomass for making biochar. Most of the biomass is already used as cooking fuel in rural and peri-urban households (BBI, 2018). Alam (2017) reported that there are maybe three potential sources for biomass feedstock in Bangladesh. These are agricultural residues, dedicated agriculture, and marginal agriculture. The most important option for biomass sources is current agricultural residues originating from crop, livestock and forest production of Bangladesh. In rural areas of Bangladesh, firewood, cow dung, leaves and twigs, branches, rice straw, and rice husk are mainly used as the biomass fuels for the cooking (Halder et al., 2014)

Table 1

Residues for Biochar Production in Bangladesh

\begin{tabular}{|c|c|c|c|c|c|c|}
\hline Field resichues & $\begin{array}{l}\text { Residue } \\
\text { Production } \\
\text { Ration } \\
\text { (RPR) }\end{array}$ & $\begin{array}{c}\text { Resicuse } \\
\text { generation( } \\
\left.10^{3} \mathrm{t}\right)\end{array}$ & $\begin{array}{l}\text { Resictues } \\
\text { recovery } \\
\left(10^{3} \mathrm{t}\right)\end{array}$ & $\begin{array}{c}\text { Resicue currently } \\
\text { available for } \\
\text { biochar production } \\
\left(10^{3} \mathrm{t}\right)\end{array}$ & $\begin{array}{l}\text { Moisture } \\
\text { content } \\
(\%)\end{array}$ & $\begin{array}{c}\text { Dry basis } \\
\text { resichue } \\
\text { available }\left(10^{3}\right. \\
\text { ton }\end{array}$ \\
\hline Rice straw & 1.69 & 58358.35 & 20425.60 & 37932.75 & 12.7 & 33115.291 \\
\hline Wheat straw & 1.75 & 1813 & 634.55 & 1178.45 & 7.5 & 1090.0663 \\
\hline Maize stalk & 2 & 4084 & 634.55 & 2654.6 & 12 & 2336.048 \\
\hline Sugarcane leaf & 0.3 & 2190 & 766.50 & 1423.5 & 50 & 683.28 \\
\hline Jute stalks & 3 & 4971 & 1739.85 & 3231.15 & 9.5 & 2924.1908 \\
\hline $\begin{array}{l}\text { Pulses } \\
\text { resicues }\end{array}$ & 1.9 & 1457.30 & 510.06 & 947.24 & 20 & 757.792 \\
\hline Millet stalk & 1.75 & 42 & 14.70 & 27.3 & 15 & 23205 \\
\hline $\begin{array}{l}\text { Groundmut } \\
\text { straw }\end{array}$ & 2.3 & 289.80 & 101.43 & 188.37 & 12.1 & 165.57723 \\
\hline $\begin{array}{l}\text { Vegetable } \\
\text { residues }\end{array}$ & 0.4 & 5288.40 & 1850.94 & 3437.46 & 20 & 2749968 \\
\hline Cotton stalk & 2.75 & 77.14 & 27 & 50.14 & 12 & 44.1232 \\
\hline Tobacco stalks & 2.0 & 158 & 55.30 & 102.7 & 8.9 & 11.297 \\
\hline Barley stalks & 1.75 & 123 & 0.43 & 0.8 & 15 & 0.68 \\
\hline $\begin{array}{l}\text { Total field } \\
\text { residues }\end{array}$ & & 78730.22 & 27555.76 & 51174.46 & & 43901.518 \\
\hline $\begin{array}{l}\text { Process } \\
\text { Residues }\end{array}$ & & & & Future availability & & \\
\hline Rice husk & 0.267 & 9192.81 & 9192.81 & 4596.405 & 12.4 & 4026.4508 \\
\hline Rice bran & 0.083 & 2857.69 & 2857.69 & 1428.845 & 9 & 1300249 \\
\hline Maize cob & 0.273 & 557.47 & 557.47 & 278.735 & 15 & 236.92475 \\
\hline Maize husk & 0.2 & 408.40 & 408.40 & 204.2 & 11.1 & 181.5338 \\
\hline $\begin{array}{l}\text { Sugarcane } \\
\text { bagasse }\end{array}$ & 0.29 & 2117 & 2117 & 1058.5 & 49 & 539.835 \\
\hline $\begin{array}{l}\text { Groundmut } \\
\text { husk }\end{array}$ & 0.477 & 60.10 & 60.10 & 30.05 & 8.2 & 27.5859 \\
\hline Coconut shells & 0.12 & 39.12 & 39.12 & 19.56 & 8 & 179952 \\
\hline Coconut husks & 0.41 & 133.66 & 133.66 & 66.83 & 11 & 59.4787 \\
\hline $\begin{array}{l}\text { Total process } \\
\text { based }\end{array}$ & & 15366.25 & 15366.25 & 7683.125 & & 6390.0531 \\
\hline $\begin{array}{l}\text { Total field + } \\
\text { Process } \\
\text { residues }\end{array}$ & & 94096.47 & 42922.01 & 58857.59 & & 50291.57 \\
\hline
\end{tabular}

Source: Alam, 2017; adapted from: Halder et al., 2014

Findings from a study conducted by Alam (2017) revealed that Bangladesh generates 78 million tons of field residues and 15 million tons of process residues in a year (Table 1). The field residues and process residues are one of the major feedstock for biochar production. Halder et al. (2014) further reported that Bangladesh produces a total of 17 million tons of forest residues each year. On the other hand, Bangladesh has a large number of livestock populations. The livestock includes cattle, buffalo, sheep, and goats. Alam (2017) reported that there were about 53 million livestock and 293 million poultry in the country in the 2012-13 fiscal year. It was estimated that the total waste generation in the same fiscal year (2012-2013) was about 83 million tons as shown in Table 2. According to Halder et al. (2014), the composition of agricultural residues in Bangladesh presented in Figure 6 
Table 2

Residues Obtained from Livestock and Poultry

\begin{tabular}{|c|c|c|c|c|c|}
\hline Livestock & Heads (millions) & $\begin{array}{l}\text { Dung yield } \\
\text { (kg/ animal/ day) }\end{array}$ & $\begin{array}{l}\text { Residues } \\
\text { generation } \\
\text { (tons / year) }\end{array}$ & $\begin{array}{l}\text { Residue } \\
\text { Recovery } \\
\text { (tons / year) }\end{array}$ & $\begin{array}{l}\text { Residue could be } \\
\text { available for biochar } \\
\text { (tons /year) }\end{array}$ \\
\hline Cattle & 23.24 & $5-10$ & 63622237.5 & 38173342.5 & 25448895 \\
\hline Goat & 25.212 & $0.25-0.5$ & 3450892.5 & 2070535.5 & 1380357 \\
\hline Sheep & 3.120 & $0.25-0.5$ & 427050 & 256230 & 170820 \\
\hline Buffalo & 1.447 & $8-12$ & 5281550 & 3168930 & 2112620 \\
\hline Pig & 0.101 & 0.8 & 29492 & 17695.2 & 11796.8 \\
\hline $\begin{array}{l}\text { Total } \\
\text { Animal }\end{array}$ & 53.121 & - & 72811222 & 43686733.2 & 29124488.80 \\
\hline Chicken & 246.60 & 0.1 & 9000900 & 4500450 & 4500450 \\
\hline Duck & 46.635 & 0.1 & 1702177.5 & 851088.75 & 851088.75 \\
\hline $\begin{array}{l}\text { Total } \\
\text { poultry }\end{array}$ & 293.235 & - & 10703077.5 & 5351538.75 & 5351538.75 \\
\hline Total & & & 83514299.5 & & 34476027.55 \\
\hline
\end{tabular}

${ }^{a}=$ recovery rate for livestock and poultry residues is $60 \%$ and $40 \%$ respectably

Source: Alom, 2017; adapted from: Halder et al., 2014

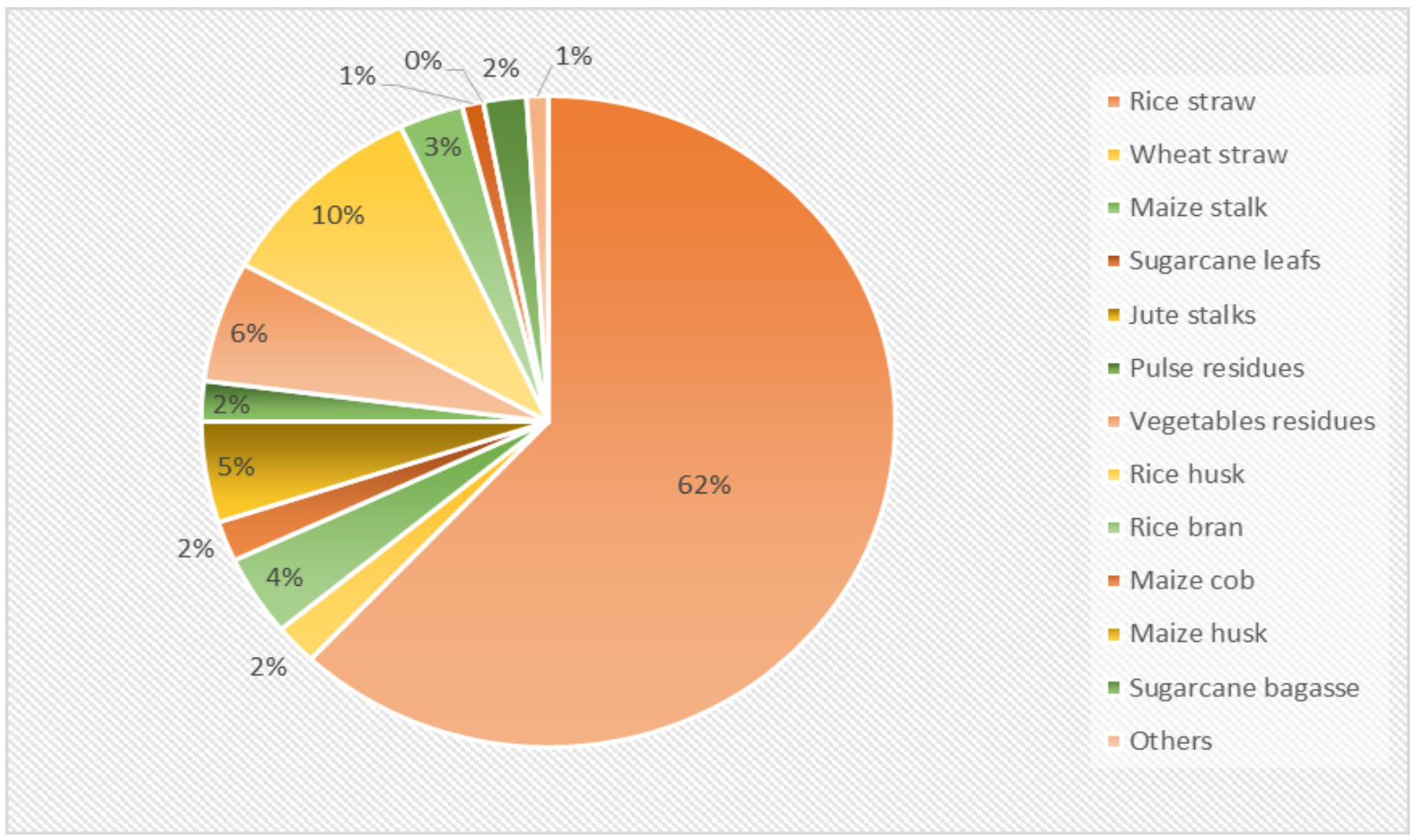

Fig. 6 Composition of agricultural residues in Bangladesh (Source: Alom, 2017, adapted from: Halder et al., 2014)

Figure 6 demonstrates that in Bangladesh, rice straw constitutes the highest sixty-two (62\%) percentage of biomass originating from the agriculture sector generating 1.69 million tons of rice straw in the country in 2012-13 FY. From this figure, it is found that the huge availability of biomass from the agriculture sector acts as a useful source of feedstock for biochar production in Bangladesh.

\section{1) Rural people perception, knowledge and attitude towards biochar production}

There are a few numbers of research works conducted on rural people's perception, knowledge, and attitude towards biochar production in Bangladesh. Though, some selected works have been presented below: 
Perception is the process of (i) identifying the stimuli received by the senses and (ii) classifying those stimuli into personally meaningful categories. The perception of respondents about biochar helps to determine the degree of awareness and idea of respondents about biochar. Haque (2019) conducted a study Biochar on soil fertility and crop productivity in Shibalaya Upazila of Manikganj district. Based on their perception of biochar, the respondents were classified into three categories such as low perception, medium perception, and high perception. This table (Table 3) revealed that an overwhelming proportion (70\%) of the respondents possessed a high level of perception while 21.7 percent of the respondents had a medium level of perception and negligible proportion $(8.3 \%)$ percent of respondents had a low level of perception on biochar. The findings indicate that the people were positively aware of biochar because of the advantageous use of biochar.

Table 3

Perception of Biochar in Shibalaya Upazila of Manikganj

\begin{tabular}{l|c|c|c|c}
\hline \multirow{2}{*}{ Categories } & \multicolumn{2}{|c|}{ Respondents } & \multirow{2}{*}{ Mean } & \\
\cline { 2 - 3 } & Number & Percent & & \\
\hline Low (below 15) & 5 & 8.3 & \\
Medium (15-30) & 13 & 21.7 & \multirow{2}{*}{33.93} & 5.77 \\
High (more than 30) & 42 & 70 & & \\
\hline \multicolumn{1}{c|}{ Total } & 60 & 100 & \\
\hline
\end{tabular}

Source: Haque (2019)

On the other hand, knowledge means awareness or familiarity gained by experience of a fact or situation. Knowledge could be awareness, principle and how to or application knowledge. Each of the knowledge categories is vital in acquiring skills for both the production and utilization of biochar. Being biochar a relatively new technology especially in the context of Bangladesh, the knowledge of people must be assessed to establish their level of comprehension which guides intervention and certainly influences policymaking, particularly concerning the rural populace. However, several studies have been conducted in line with this. For instance, Fardaus (2017) conducted a study on knowledge of tribal women on biochar promotion for homestead gardening in Nawabgang Upazila under the Dinajpur district with the support of the Christian Commission for Development in Bangladesh (CCDB). She found that the majority (36.3\%) of the tribal women had high knowledge followed by $34.3 \%$ had low knowledge and $29.4 \%$ had medium knowledge on biochar. Findings revealed that more than half $(63.70 \%)$ of the tribal women had low to medium knowledge on biochar. Similar results were reported by Azad (2013).

Table 4

Knowledge on Biochar Nawabganj Upazila of Dinajpur

\begin{tabular}{l|c|c|c|c}
\hline \multirow{2}{*}{ Categories } & \multicolumn{2}{|c|}{ Respondents } & \multirow{2}{*}{ Mean } & \multirow{2}{*}{ SD } \\
\cline { 2 - 3 } & No. & \% & \multirow{2}{*}{33.04} & \multirow{2}{*}{18.70} \\
\hline Low (up to 22) & 35 & 34.3 & \\
\hline Medium (23-44) & 30 & 29.4 & & \\
\hline High (above 44) & 37 & 36.3 & & \\
\hline \multicolumn{1}{c|}{ Total } & $\mathbf{1 0 2}$ & $\mathbf{1 0 0}$ & & \\
\hline
\end{tabular}

Source: Fardaus (2017)

Attitude is a predisposition or a tendency to respond positively or negatively towards a certain idea, object, person, or situation. Attitudes could be explicit attitude i.e. consciously aware of, that clearly influence our behaviours and beliefs while implicit attitudes are unconscious, but still have an effect on our beliefs and behaviours. The biochar production and utilization activities are new for the farmers although they respond positively because of the support of the implementing organization. Barman (2017) researched Bangladesh on attitude towards biochar production and utilization. From this Table, the findings indicates that the majority of about $92.3 \%$ of the farmers showed moderately favourable to a highly favourable attitude towards biochar production and utilization for sustainable agriculture. 
Table 5

Attitude towards Biochar in Nawabganj Upazila of Dinajpur

\begin{tabular}{l|c|c|c|}
\hline \multirow{2}{*}{ Categories } & \multicolumn{2}{|c|}{ Respondents (N=104) } & \multirow{2}{*}{ Mean } \\
\cline { 2 - 4 } & Number & 7.7 & \\
\hline Slightly favorable $(\leq 20)$ & 8 & 15.38 & 48.64 \\
\hline Moderately favorable(21-40) & 16 & 76.92 & 5.96 \\
\hline Highly favorable $(\geq 41)$ & 80 & \\
\hline
\end{tabular}

Source: Barman (2017)

From the same study, the attitude was measured using rank-order analysis. It reveals the attitude indices of tribal farmers' attitude towards biochar production and utilization for sustainable agriculture is shown in Table 5.

Information contained in Table 6 revealed that the statements such as "Biochar production is smokefree and safe for women and children health" had an AI value of 459 ranked first (1). This could be due to that this Akha is helping the healthy environment in the kitchen, easy to use through any kind of biomass, less smoke and less expensive. It reduces carbon dioxide during cooking and helping reducing carbon in the air (GHGs) and mitigating climate change. "Production and utilization of biochar is an environment and agriculture friendly" had an AI value of 459 and ranked 2. This might be due to clean cooking Akha helps women and children's health. Information contained in Table 6 revealed that the statement "Price of Akha is higher than other cooking stoves" and "using Biochar can reduce the soil water holding capacity" is the jointly second last ranked statement in the attitude index table having AI value of 382. This might be due to preservation of biochar is easy for them.

Table 6

Attitude Indices towards Biochar Production and Utilization

\begin{tabular}{|c|c|c|c|c|c|c|c|c|}
\hline \multirow{2}{*}{ S\# } & \multirow{2}{*}{ Statements } & \multicolumn{5}{|c|}{ Frequency of the Respondents } & \multirow{2}{*}{${ }^{1} \mathbf{A I}$} & \multirow{2}{*}{${ }^{2}$ RO } \\
\hline & & SA & $\mathbf{A}$ & NO & DA & SD & & \\
\hline \multicolumn{9}{|c|}{ Related to Production } \\
\hline 1.(+) & $\begin{array}{l}\text { Biochar can be easily produced through the } \\
\text { cooking stove Akha }\end{array}$ & 0 & 3 & 18 & 71 & 12 & 404 & $7^{\text {th }}$ \\
\hline 2.(-) & $\begin{array}{l}\text { Price of Akha is higher than other cooking } \\
\text { stove }\end{array}$ & 3 & 67 & 31 & 3 & 0 & 382 & $11.5^{\text {th }}$ \\
\hline 3.(+) & $\begin{array}{l}\text { Heat of Akha is more efficient than } \\
\text { traditional cooking process }\end{array}$ & 0 & 0 & 27 & 56 & 21 & 410 & $5^{\text {th }}$ \\
\hline 4.(-) & $\begin{array}{l}\text { Temperature control during cooking in Akha } \\
\text { is not easy }\end{array}$ & 18 & 63 & 21 & 2 & 0 & 409 & $6^{\text {th }}$ \\
\hline 5.(+) & $\begin{array}{l}\text { Biochar production is smoke free and safe } \\
\text { for women and children health }\end{array}$ & 0 & 2 & 15 & 25 & 62 & 459 & $1^{\mathrm{st}}$ \\
\hline 6.(-) & Production of Biochar is laborious task & 18 & 51 & 32 & 3 & 0 & 396 & $9^{\text {th }}$ \\
\hline \multicolumn{9}{|c|}{ Related to Utilization } \\
\hline 7. $(+)$ & $\begin{array}{l}\text { Biochar retains soil organic matter for life- } \\
\text { long period }\end{array}$ & 2 & 4 & 16 & 38 & 44 & 430 & $3^{\text {rd }}$ \\
\hline 8. (-) & $\begin{array}{l}\text { Biochar is not available enough for using } \\
\text { large scale crop field }\end{array}$ & 24 & 41 & 37 & 2 & 0 & 399 & $8^{\text {th }}$ \\
\hline 9.(+) & $\begin{array}{l}\text { Biochar can enhance the yield and quality } \\
\text { of crops }\end{array}$ & 0 & 4 & 15 & 51 & 34 & 427 & $4^{\text {th }}$ \\
\hline $10 .(-)$ & $\begin{array}{l}\text { Biochar produced crops are unsafe for } \\
\text { human health }\end{array}$ & 8 & 57 & 37 & 2 & 0 & 383 & $10^{\text {th }}$ \\
\hline 11.(-) & $\begin{array}{l}\text { Using Biochar can reduce the soil water } \\
\text { holding capacity }\end{array}$ & 4 & 68 & 26 & 6 & 0 & 382 & $11.5^{\text {th }}$ \\
\hline 12.(+) & $\begin{array}{l}\text { Utilization of biochar is environment and } \\
\text { agriculture friendly }\end{array}$ & 0 & 3 & 21 & 20 & 60 & 449 & $2^{\text {nd }}$ \\
\hline
\end{tabular}

$\mathrm{SA}=$ Strongly Agree; $\mathrm{A}=$ Agree; $\mathrm{NO}=$ No Opinion; $\mathrm{DA}=$ Disagree and $\mathrm{SD}=$ Strongly Disagree; ${ }^{1} \mathrm{AI}=\mathrm{Attitude}$ Index and ${ }^{2} \mathrm{RO}=$ Rank Order

Source: Barman (2017) 


\section{B. Use and Performance of Biochar Producing the Cooking Stove}

An improved stove can be designed to increase energy efficiency, eliminate smoke from the indoor living space, or decrease the drudgery of cooking duties. Many models were designed for improved stove programs so that the poorest customers could afford them (World Bank, 2011).WHO and UNDP (2009) reported that the mere mention of "improved cookstoves" may conjure up images of millions of cook stoves now broken or long since disposed of rather than the 166 million cookstoves still being used (Figure 7). Among the different Countries in the

World, only China has a high percentage of households that have adopted better cookstoves. While about 40 percent adoption in the other regions has generally been much lower.

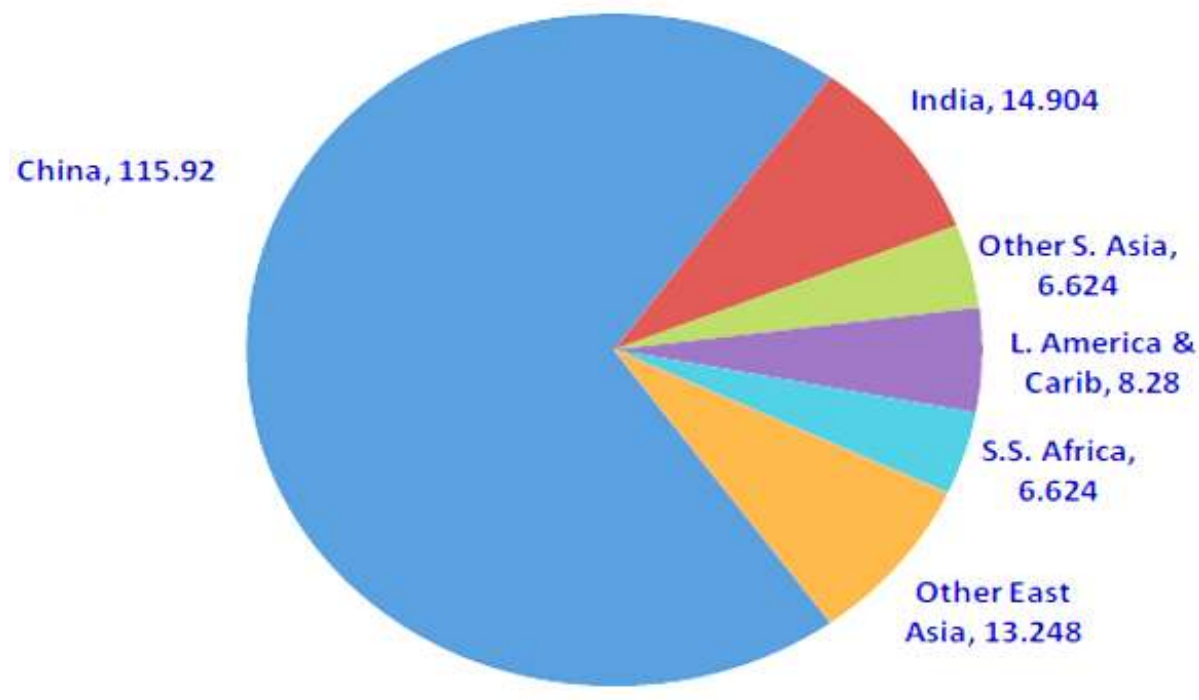

Fig. 7 Improved Cooking Stoves (millions) (Adapted from: WHO and UNDP, 2009)

Among all of the improved cook stoves used over the world, the most common biochar producing cooking stove is called a top-tilt updraft gasifier (TLUD). BBI (2018) reported that top-lit updraft (TLUD) gasifiers automatically make biochar in the process of cooking and the technology is relatively simple. A TLUD is a canister filled with a small piece of fuel or biomass which is called a fuel bed. Air can enter the canister through holes in a grate at the bottom and at the top of the cylinder, above the fuel bed. The top of the fuel bed is ignited through wetted with kerosene. An ignition front is formed that moves down through the fuel-producing white smoke and leaving unburned char above. The ignition front is supported by the air (primary air) that enters the bottom of the cylinder. The white smoke is flammable and burns at the top of the TLUD for cooking. This gas flame is supported with air (secondary air) entering through side-holes or a gap near the top of the cylinder.
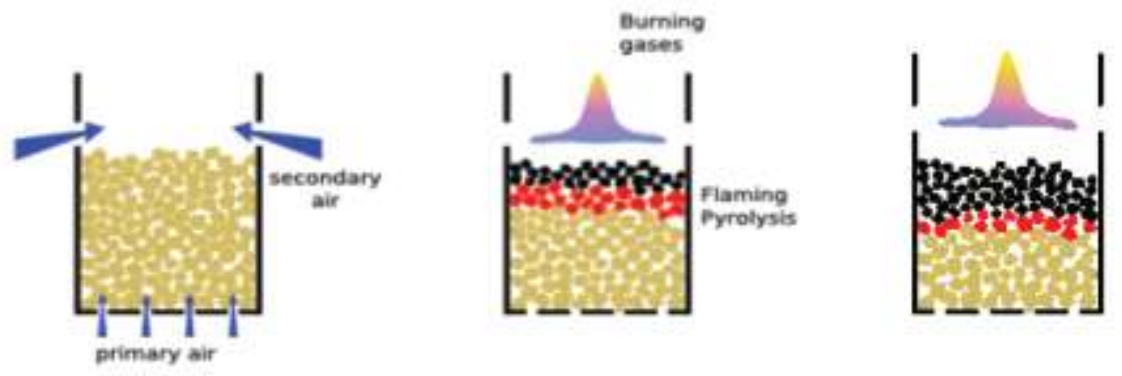

Fig. 8 Picture of a typical of biochar producing TLUD (Adapted from: BBI, 2018)

When the ignition front reaches the bottom of the cylinder, the smoke-producing reaction is complete, and the gas fire goes out. At this point, the char is removed from the cylinder, and use for biochar. (BBI, 2018) 
The Bangladesh Biochar Initiative, 2018 stated in the TLUD-Biochar Ecology blog that, TLUD stoves are dissimilar from other biomass cook stoves because they inevitably make char as a by-product of cooking. Since char has numerous applications as charcoal and biochar, the TLUD stove becomes crucial to other activities, both in the household and in the broader community. This expanded function of the stove provokes a much extensive view of its role in the economy. They called this view 'TLUD-Biochar Ecology'. The following figure 9 showed that the TLUD cooking stoves unbolt new opportunities in households and communities. The household possibilities are the use of biochar to enrich the fertility of the soil and organic waste management to increases the yields of crops. On the other hand, the fuel energy uses more than $50 \%$ by burning charcoal and increases the overall efficiency of energy. Char can be sold into the market to increase household income. In the community side, the char can be used as charcoal in a variety of small businesses (forges, tea stalls, restaurants), and as biochar in biotechnology (water filtration, waste management, fertilizers, etc.) In the individual perspective the Lower total fuel consumption, higher crop yield and net household income improve the finance as well as the economy of the community.

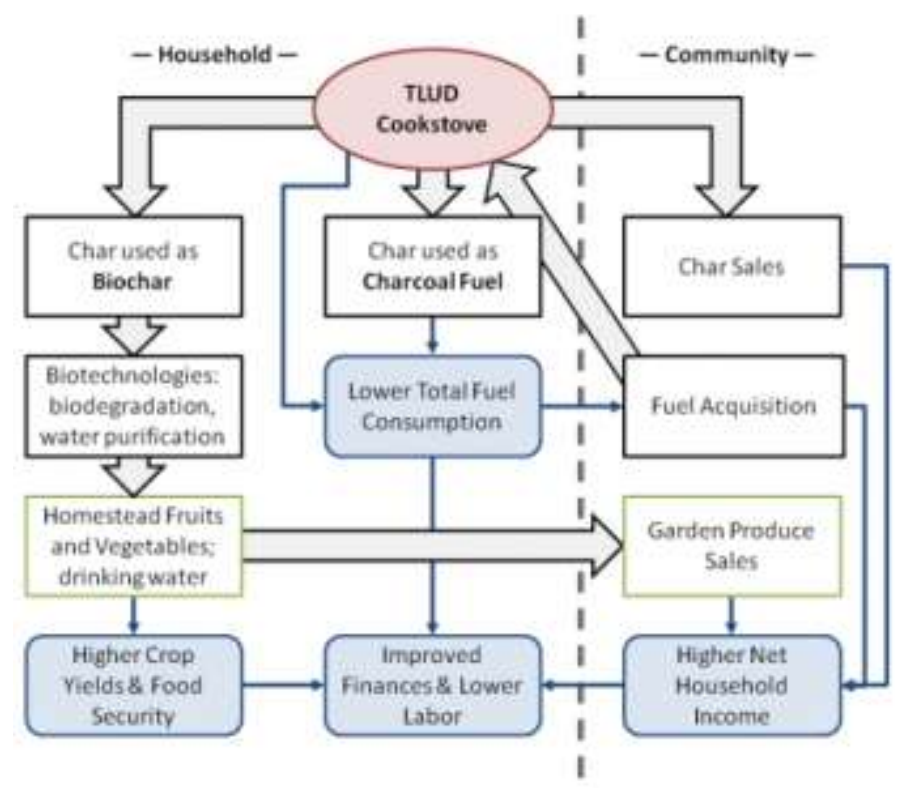

Fig. 9 The consequence of a char-making TLUD for a household and community (Source: BBI, 2018)

\section{Bangladeshi TLUD}

According to the Bangladesh Biochar Initiative (BBI), introducing biochar for agriculture, the first challenge they face that is how to get biochar. BBI is a volunteer endeavour for promoting biochar, fostered by the Christian Commission for Development in Bangladesh (CCDB), which was formed in 1973, as a national level non -government organization. The BBI was founded in 2013 to foster the use of Biochar through reforming the renewable energy-making process, enhancing organic matter, crop productivity and mitigating climate change (Karim and Islam, 2018). In these circumstances, the CCDB development policy advisor Md Mahbubul Islam and Canadian scientist Professor Dr. Julian Winter recently invented low-cost natural draftTop-Lit-Up-Draft (TLUD) gasifier stove (local name Akha) which is an environment and agriculture friendly. It can be used for cooking and heating with locally available biomass. The Akha is a type of natural draft (ND), a top-lit updraft gasifier (Figure 10). The basic operating principle of an ND.TLUD is quite simple and compatible with the cooking habits of Bangladeshi women. The imported TLUDs is not feasible in Bangladesh without subsidization (e.g., carbon credits).The Akha Chula is a Bangladeshi TLUD.TLUD cook stoves can achieve cooking efficiencies between $30-40 \%$ (compared to $10 \%$ for a traditional Chula and $30 \%$ for an improved Chula) and produce biochar as a by-product. 

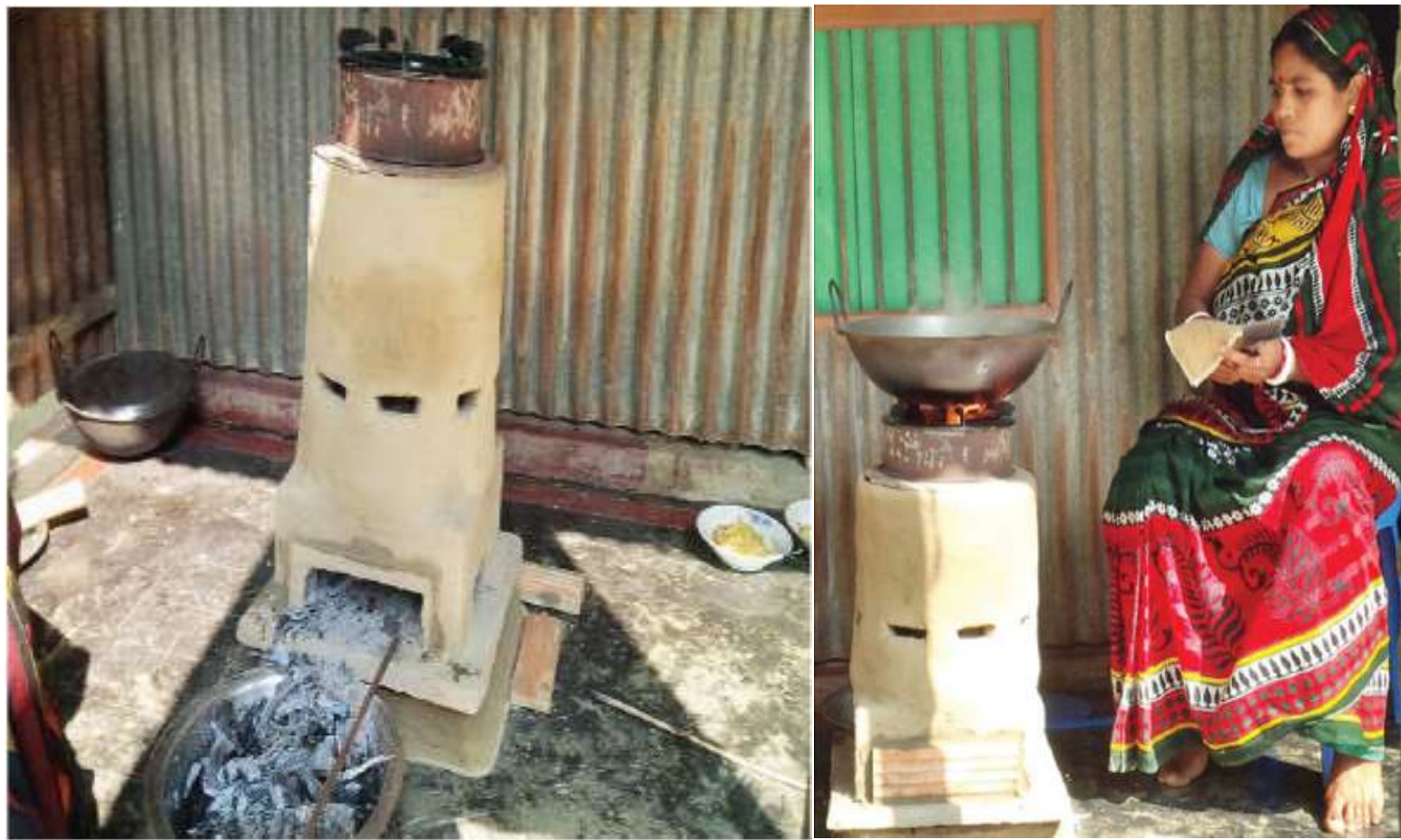

Fig. 10 Eco-friendly TLUD cooking stoves and by-product biochar (Adapted from: Siddique, 2016)

Usually, Biochar User Group (BUG) members participate in Akha's evaluation and development (Figure 11). The Akha is like cooking with gas. This is a sophisticated stove that produces very low smoke. They like the consistent production of heat without stoking, leaving them free to do other tasks. They do not mind that the Akha is taller than a traditional stove and like standing to cook. The production of biochar is a very important reason for using the $A k h a$, but the process does involve a series of necessary activities (Table 7) in which the members of BUG engage. They do find breaking wood into small pieces is a chore (BBI, 2018).

Table 7

Biochar Production Activities through Akha Chula

\begin{tabular}{l|l|c|c|c|c|c|c}
\hline \multirow{2}{*}{ S\# } & \multirow{2}{*}{ Biochar Production Activities } & \multicolumn{3}{|c|}{ Frequency of respondents } & \multirow{2}{*}{ PI } & \multirow{2}{*}{ Rank } \\
\cline { 3 - 7 } & & Not at all (0) & Seldom (1) & Often (2) & Regular (3) & & \\
\hline 1. & Cleaning the Akha Chula & 46 & 4 & 4 & 48 & 159 & $4^{\text {th }}$ \\
\hline 2. & Keeping fuel in Akha Chula & 41 & 3 & 9 & 50 & 171 & $1^{\text {st }}$ \\
\hline 3. & Firing fuel of Akha Chula & 42 & 3 & 7 & 50 & 170 & $2^{\text {nd }}$ \\
\hline 4. & Temperature control & 47 & 32 & 9 & 14 & 92 & $6^{\text {th }}$ \\
\hline 5. & Staying while cooking & 47 & 2 & 3 & 50 & 158 & $5^{\text {th }}$ \\
\hline 6. & Collecting biochar after cooking & 39 & 4 & 16 & 43 & 168 & $3^{\text {rd }}$ \\
\hline
\end{tabular}

$\mathrm{PI}=$ Participation Index

Source: Kisku (2017) 


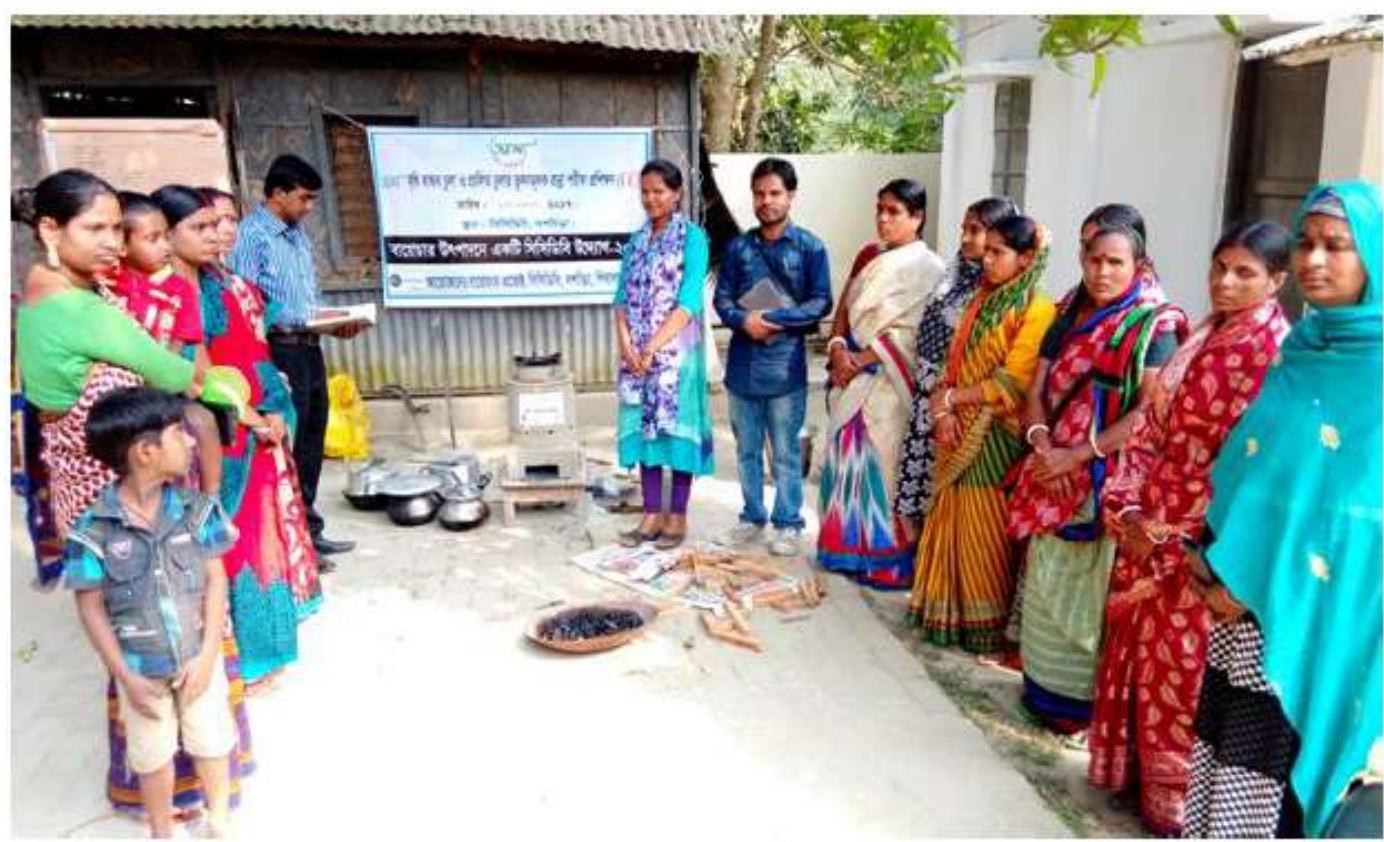

Fig. 11 Participants of a TLUD training session in Manikganj district (Adapted from: BBI, 2018)

\section{Performance of TLUD}

Performance is usually the fulfilment of an obligation, in a manner that relieves an individual or a people from responsibilities initially agreed upon. It is measured against preset known standards of accuracy, completeness, cost, and speed. In terms of performance, TLUD saves a lot of cost for fuel and maximizes time utilization. Anand (2015) reported that on comparative fuel cost and timing efficiency of TLUD over traditional clay stove (Table 8), where it was revealed to be user-friendly and cost-effective.

Table 8

Performance of TLUD Stove

\begin{tabular}{|c|c|c|c|c|c|c|}
\hline Food Items & $\begin{array}{l}\text { Amount of } \\
\text { fuelwood (in } \\
\text { Kg) in the } \\
\text { clay stove }\end{array}$ & $\begin{array}{l}\text { Timing } \\
\text { (Mins) }\end{array}$ & $\begin{array}{c}\text { Amount of } \\
\text { fuelwood } \\
\text { used (in kg) } \\
\text { in TLUD } \\
\text { stove }\end{array}$ & $\begin{array}{l}\text { Timing } \\
\text { (Mins) }\end{array}$ & $\begin{array}{c}\text { Charcoal } \\
\text { weight } \\
\text { (gram) }\end{array}$ & $\begin{array}{c}\text { Saved } \\
\text { fuelwood } \\
(\%)\end{array}$ \\
\hline Rice & 1.41 & 28.26 & 0.97 & 25.52 & \multirow{6}{*}{$\begin{array}{l}296.60 \text { (for } \\
\text { cooking } \\
\text { three food } \\
\text { items) }\end{array}$} & 45.51 \\
\hline Dalma & 0.39 & 8.28 & 0.30 & 7.54 & & 31.33 \\
\hline Mandiya & 0.81 & 16.32 & 0.56 & 15.04 & & 45.50 \\
\hline Vegetable & 0.24 & 5.28 & 0.19 & 4.54 & & 30.76 \\
\hline Fry & 0.27 & 5.36 & 0.21 & 5.18 & & 32.71 \\
\hline Atani & 0.37 & 7.46 & 0.28 & 7.12 & & 34.05 \\
\hline
\end{tabular}

From the above table, the author showed that the different food item's needs different amount of fuel wood in the traditional cookstove and TLUD stove and also the timing of the preparation of the food. From the table, it was found that to the preparation of different food items more fuel wood requires in clay stove and also takes more time than the TLUD cook stove. 
Table 9

Reason for an advocacy-TLUD Cook stove

\begin{tabular}{|c|c|c|}
\hline \multirow[t]{2}{*}{ Reason for advocacy-TLUD cook stove in Odisha state India } & \multicolumn{2}{|c|}{ Percent } \\
\hline & Yes & No \\
\hline Is it a useful product? & 100 & 0 \\
\hline Will you suggest to your friend and family? & 98 & 2 \\
\hline Can it save the cost? If biomass is not freely available & 100 & 0 \\
\hline Can it reduce drudgery? Reduce time taken to gather fuel wood & 100 & 0 \\
\hline Reduce the consumption of fuel wood & 100 & 0 \\
\hline Ease of Use & 100 & 0 \\
\hline Ease of maintenance & 80 & 20 \\
\hline Ease of size fuel wood to put in the canister & 100 & 0 \\
\hline Durability of stove & 100 & 0 \\
\hline Ability to withstand rough handling & 40 & 60 \\
\hline Ease of working with the flame (starting it, controlling the flame, extinguishing the flame etc.) & 34 & 66 \\
\hline Ability to cater to my cooking requirement & 82 & 18 \\
\hline provide adequate cooking duration & 56 & 44 \\
\hline Provide adequate flame power & 70 & 30 \\
\hline Reduce smoke & 80 & 20 \\
\hline Enables faster cooking & 100 & 0 \\
\hline Free time for other activities & 98 & 2 \\
\hline Does not require constant supervision & 0 & 100 \\
\hline TLUD being suitable to all my cooking vessel & 84 & 16 \\
\hline
\end{tabular}

Source: Anand(2015)

From the same research carried out by Anand (2015) in Odisha state, India found the reason for advocacy for TLUD cook stove is presented in Table 9 where all respondents opined the usefulness product, cost-saving, reduction of drudgery, and consumption of fuel wood, ease to use, ease to size fuel wood and durability. Another interesting aspect of the TLUD cooking stove is that it does not require constant supervision.

In North Vietnam, a group of stove experts and researchers working with CARE Vietnam found that the most efficient and fastest stove was DK-B1 (analogous to TLUD) which used approximately $60 \%$ less fuel than the open fire and produced approximately $190 \mathrm{~g}$ biochar. Preliminary analysis of the flue gas from three stoves (Figure 12) was taken using a portable gas analyser during the initial water boiling stage of the rice cooking and the initial results were encouraging (Table 10).

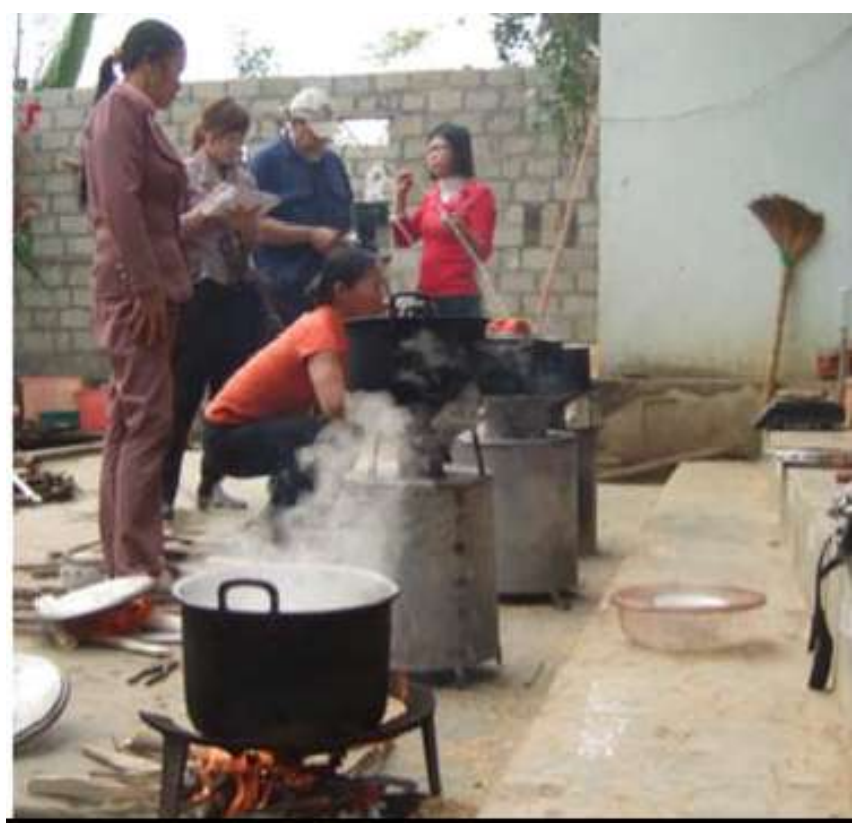

Fig. 12 Comparison of three stoves (DK-B3, DK-B2, and DK-B1) against an open fire (Adapted from: Joseph et al., 2012) 
Table 10

Trials Outcomes of three Stoves against the Traditional Stove in Vietnam

\begin{tabular}{l|c|c|c|c}
\hline \multicolumn{1}{c|}{ Characteristics } & DK-B3 & DK-B2 & DK-B1 & Open fire \\
\hline The amount of used wood (gram) & 1235 & 970 & 955 & 2000 \\
\hline The amount of used biomass (gram) & 600 & 960 & 965 & 730 \\
\hline The biochar (gram) & 105 & 185 & 190 & 315 \\
\hline Total weight wood- 1.5x total weight biochar & 1078 & 693 & 670 & 1528 \\
\hline total weight of food (gram) & 1850 & 1850 & 1850 & 1850 \\
\hline Total weight food/total weight wood & 1.50 & 1.91 & 1.94 & 0.93 \\
\hline Total time for cooking rice to simmer (Minutes) & 30.00 & 34.00 & 29.00 & 32.00 \\
\hline
\end{tabular}

Adapted from: Joseph et al. (2012)

The team tested the three new stoves at BinhThanh commune with a controlled cooking test. At the start of the test, women (just like BUG members) were given the same amount and type of fuel and food and were requested to cook rice, pork and a bowl of vegetable soup. A mixture of rice straw, rice husks, and bamboo were used in the pyrolysis chamber of the stove. The results of these tests are given in Table 10.

In another study from sub-Saharan Africa, Magnusson (2015) researched introduction and diffusion of biochar as a soil amendment and biochar producing stoves in Kenya, it was found that most of the households had more than one type of stove, however, the most commonly used was the traditional three stones stove with firewood as feedstock. It was observed that $60 \%$ of the households used this type of stove usually for cooking. It was also observed in the study that, different types of improved jikos (19\%), charcoal jiko (9\%), gas cooker (7\%), and kerosene stove or electric oven or kettle (5\%) used respectively. He also found that the main reasons for the interest in TLUD like stoves were due to time-saving (40\%), to reduce smoke (23\%), to reduce costs $(19 \%)$ and in order to save firewood and preserve the environment $(12 \%)$.

\section{Problems Faced in Biochar Production and Utilization}

They're bound to be challenges or problems in any workable technology, so, in the production and utilization of biochar the TLUD and Akha Chula are not left out, including the users. An overall picture of such has been given by Gwenzi et al. (2015) from evidences observed in sub Saharan Africa (Figure 13).

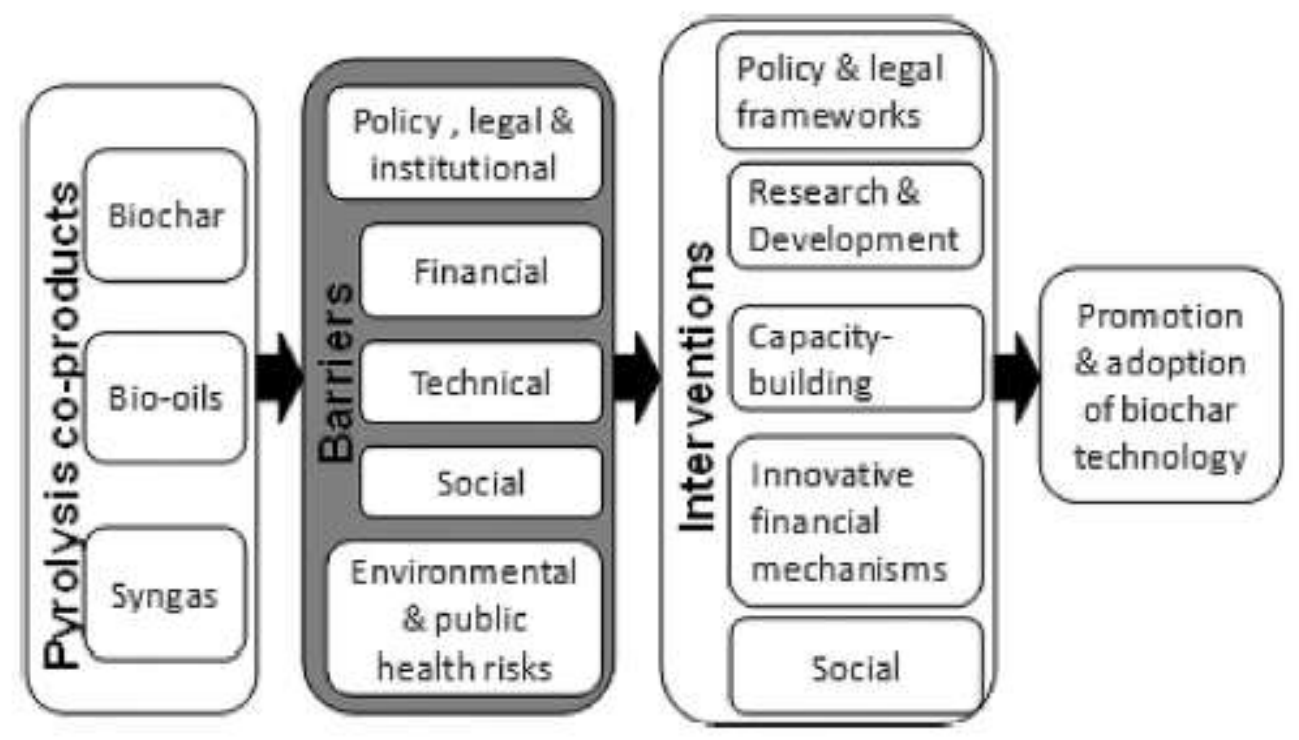

Fig. 13.Barriers to the production and application of biochar (Adapted from: Gwenzi et al., 2015) 
In Bangladesh, Jayntto (2017) researched farmers' attitudes towards biochar production and utilization for sustainable agriculture. In the study, farmers reported several problems faced during biochar production and utilization especially with regards to raw materials, awareness, and management (Table 11).

Table 11

Problems Faced in Biochar Production and Utilization

\begin{tabular}{c|l|c|c|c|c|c|c}
\hline \multirow{2}{*}{ S\# } & \multirow{2}{*}{ Problems } & \multicolumn{3}{c|}{ Percent of the beneficiaries } & \multirow{2}{*}{${ }^{\mathbf{1}}$ PFI } & \multirow{2}{*}{ RO } \\
\cline { 3 - 6 } & & Not at all & Low & Medium & High & & \\
\hline 1. & Lack of woody fuel material & 9 & 6 & 45 & 44 & 228 & $1^{\text {st }}$ \\
\hline 2. & Need kerosene for initial fire & 19 & 34 & 34 & 17 & 153 & $3^{\text {rd }}$ \\
\hline 3. & Lack of Akha Chula in the market & 28 & 41 & 25 & 10 & 121 & $5^{\text {th }}$ \\
\hline 4. & Storage problem of biochar & 55 & 48 & 1 & 0 & 50 & $7^{\text {th }}$ \\
\hline 5. & Lack of information about Akha & 27 & 50 & 24 & 3 & 107 & $6^{\text {th }}$ \\
\hline 6. & $\begin{array}{l}\text { Time-consuming to crushing before use } \\
\text { of biochar }\end{array}$ & 3 & 16 & 49 & 36 & 222 & $2^{\text {nd }}$ \\
\hline 7. & $\begin{array}{l}\text { Lack of biochar for use in the large } \\
\text { scale crop field }\end{array}$ & 24 & 26 & 37 & 17 & \multirow{2}{*}{151} & $4^{\text {th }}$ \\
\hline
\end{tabular}

${ }^{1} \mathrm{PFI}=$ Problem Faced Index and ${ }^{2} \mathrm{RO}=$ Rank Order

Source: Barman (2017)

The findings of Barman (2017) emphasized the unavailability of information to the farmers and limited extension contact which reduces the rate at which they would have the wish to move in terms of production and utilization of biochar. Besides, internet sources were not above to demonstrate practical methods. Information in Table 12 revealed the findings of Kisku (2017) from a study conducted at Nawabgonj Upazila of Dinajpur district where the respondents largely reported the collection and preparation of the raw material as the major problems to production and utilization of biochar.

Table 12

Problems Faced In Biochar Production and Preservation

\begin{tabular}{|c|c|c|c|c|}
\hline S\# & Problems & No. of Citation & Percent & Ranking \\
\hline 1 & Difficulty in fuel wood collection & 72 & 70.59 & $1^{\text {st }}$ \\
\hline 3 & Only two food items can be cooked & 62 & 60.79 & $3^{\text {rd }}$ \\
\hline 5 & Habit on the traditional cookstove & 37 & 36.28 & $5^{\text {th }}$ \\
\hline 6 & Unavailability of Akha Chula & 30 & 29.42 & $6^{\text {th }}$ \\
\hline
\end{tabular}

Source: $\operatorname{Kisku(2017)}$

However, all the findings presented in this subsection have stressed problems affecting biochar production and utilization. These problems are compounded by accessibility, policy frameworks, and information flow to the people. By and large, overcoming the problems would certainly enhance the production and utilization of biochar.

\section{CONCLUSIONS}

Based on the findings and their logical harmonization the present paper makes the following conclusions:

1) Biochar production and utilization are quite efficient with global acceptability and high potential in overcoming climate change consequences due to carbon emission. In rural Bangladesh, the perception is very positive, knowledge is appreciable and attitude is highly positive concerning agriculture uses and environmental friendliness.

2) The performance of biochar producing cooking stove has so far been wonderful especially in rural Bangladesh despite the reported inadequacy of its supply. The use of the stoves has been highly welcomed 
by the rural populace especially in the northern part of the country. But, more needs to be done in the area of training and identification/accessibility of raw materials and information on biochar production and utilization.

3) There are several problems confronted in biochar production and utilization. These range from financial, technical, social, public health and policy frameworks. In Bangladesh particularly, the rural populace has been mostly reported to encounter difficulties in gathering raw materials, limited access to information, and storage of the produced biochar.

\section{REFERENCES}

[1] Alam, M. O. (2017). The Economic Feasibility of Biochar Production and Utilization in Bangladesh. International Journal of Business, Social and Scientific Research 6(1): 93-102. Retrieve from http://www.ijbssr.com/currentissueview/14013244c

[2] Azad, M.J. (2013). Farmers' Knowledge on Post-harvest Practices of Vegetables. M.S. Thesis, Department of Agricultural Extension and Information System, Sher-e-Bangla Agricultural University, Mymensingh, Bangladesh.

[3] Bailis, R. (2009). Modeling climate change mitigation from alternative methods of charcoal production in Kenya. Biomass and Bioenergy, 33(11), 1491-1502.

[4] Barman, J.K. (2017). Tribal Farmers' Attitude towards Biochar Production and Utilization for Sustainable Agriculture. MS Thesis, Department of Agricultural Extension. HSTU, Dinajpur.

[5] Barrow, C. J. (2012). Biochar: potential for countering land degradation and for improving agriculture. Applied Geography, $34,21-28$.

[6] BBI (Bangladesh Biochar Initiative). (2015). Sponsored by the Christian Commission for Development in Bangladesh. Available at: http://www.biochar-bangladesh.org

[7] BBI (Bangladesh Biochar Initiative). (2018). Sponsored by the Christian Commission for Development in Bangladesh. Available at: http://www.biochar-bangladesh.org

[8] Cui, Z. (2015). 498 Research Paper: A Review of Biochar's Applications in the Soil Nitrogen Cycle. New Mexico State University.

[9] Duer, M. J. (2004). Introduction to Solid-State NMR Spectroscopy. Blackwell, Oxford.

[10] Duku, M. H., Gu, S., \& Hagan, E. B. (2011). Biochar production potential in Ghana—a review. Renewable and Sustainable Energy Reviews, 15(8), 3539-3551.

[11] FAO (Food and Agriculture Organization of the United Nations). (2010). What Wood fuels Can Do to Mitigate Climate Change. FAO Forestry Paper No. 162. Rome: Food and Agriculture Organization of the United Nations.

[12] Ferdaus, T. (2017). Knowledge of Tribal Women on Biochar Promotion for Homestead Gardening. MS Thesis, Department of Agricultural Extension. HSTU, Dinajpur.

[13] Gwenzi, W., Chaukura, N., Mukome, F. N., Machado, S., \&Nyamasoka, B. (2015). Biochar production and applications in subSaharan Africa: Opportunities, constraints, risks and uncertainties. Journal of environmental management, 150, $250-261$.

[14] Halder, P. K., Paul, N., \& Beg, M. R. A. (2014). Assessment of biomass energy resources and related technologies practice in Bangladesh. Renewable and Sustainable Energy Reviews, 39, 444-460.

[15] Haque, M.M. (2019). Biochar on Soil Fertility and Crop Productivity in Shibalaya Upazila of Manikganj District. MS Thesis, Department of Soil Science. BSMRAU, Gazipur.

[16] IBI (International Biochar Initiative). 2012. "Developing Guidelines for Specifications of Biochars." http://www.biocharinternational.org/characterizationstandard.

[17] Joseph, S., Khoi, D. D., Hien, N. V., Anh, M. L., Nguyen, H. H., Hung, T. M., \& Chia, C. H. (2012). North Vietnam Villages Lead the Way in the Use of Biochar: Building on an Indigenous Knowledge Base. International Biochar Initiative. Availbale from: http://www. biochar-international. org/sites/default/files/CARE_Vietnam_1, 31 .

[18] Karim, M. R \& Islam, M. M. (2018). Scope and Constraints for Biochar Promotion for Renewable Clean Energy, Sustainable Agriculture and Climate Change Mitigation. Unpublished research report for the Akha-Biochar Project, submitted to the Christian Commission for Development in Bangladesh, Dhaka. 11 p.

[19] Kisku, P. (2017). Tribal Women's' Participation in Biochar Production and Preservation.MS Thesis, Department of Agricultural Extension. HSTU, Dinajpur.

[20] Krull, E., Lehmann, J., Skjemstad, J., Baldock, J., \&Spouncer, L. (2008). The global extent of black C in soils: is it everywhere. Grasslands: Ecology, Management and Restoration. Nova Science Publishers, Inc, 13-17. 
[21] Leach, M., Fairhead, J., Fraser, J., \&Lehner, E. (2010). Biocharred pathways to sustainability? Triple wins, livelihoods and the politics of technological promise.

[22] Lehmann, J. (2009). Terra preta Nova-where to from here? In Amazonian Dark Earths: WimSombroek's Vision (pp. 473-486). Springer, Dordrecht.

[23] Magnusson, A. (2015). Improving small-scale agriculture and countering deforestation: the case of biochar and biochar producing stoves in Embu County, Kenya.

[24] McLaughlin, H., Anderson, P. S., Shields, F. E., \& Reed, T. B. (2009, August). All biochars are not created equal, and how to tell them apart. In Proceedings, North American Biochar Conference, Boulder, Colorado (pp. 1-36).

[25] Mwampamba, T. H., Owen, M., \&Pigaht, M. (2013). Opportunities, challenges and way forward for the charcoal briquette industry in Sub-Saharan Africa. Energy for Sustainable Development, 17(2), 158-170.

[26] O’neill, B., Grossman, J., Tsai, M., Gomes, J. E., Lehmann, J., Peterson, J. \&Thies, J. E. (2009). Bacterial community composition in Brazilian Anthrosols and adjacent soils characterized using culturing and molecular identification. Microbial ecology, 58(1), 23-35.

[27] Panwar, N. L., Pawar, A., \&Salvi, B. L. (2019). Comprehensive review on production and utilization of biochar. SN Applied Sciences, 1(2), 168.

[28] Scholz, S. B., Sembres, T., Roberts, K., Whitman, T., Wilson, K., \& Lehmann, J. (2014). Biochar systems for smallholders in developing countries: leveraging current knowledge and exploring future potential for climate-smart agriculture. The World Bank.

[29] Siddique, A. (2016). Biochar: An eco-friendly fertilizer. Dhaka Tribune, December $11 . \quad$ Retrieved from: http://www.dhakatribune.com/bangladesh/2016/12/11/biochar-eco-friendly-fertiliser/

[30] Skjemstad, J. O., Reicosky, D. C., Wilts, A. R., \& McGowan, J. A. (2002). Charcoal carbon in US agricultural soils. Soil Science Society of America Journal, 66(4), 1249-1255.

[31] WHO (World Health Organization) and UNDP (United Nations Development Program). (2009). The Energy Access Situation in Developing Countries. New York: United Nations Development Program.

[32] Woolf, D., Amonette, J. E., Street-Perrott, F. A., Lehmann, J., \& Joseph, S. (2010). Sustainable biochar to mitigate global climate change. Nature communications, 1, 56.

[33] World Bank. (2011). Household cookstoves, environment, health, and climate change: A new look at an old problem. Washington, DC: World Bank. 